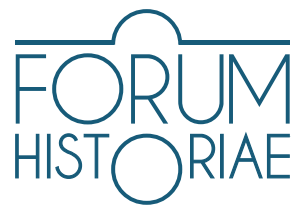

\title{
Italy and Post-Habsburg Central Europe (An Introduction)
}

\author{
Michal Kšiňan - Michal Ďurčo
}

\begin{abstract}
KŠIŇAN, Michal - ĎURČO, Michal. Italy and Post-Habsburg Central Europe.

This is an introduction to the thematic issue of Forum Historiae 1/2021, Italy and the Post-Habsburg Central Europe, which outlines the main research questions and hypotheses that the authors worked with. Italy had ambitions to be in the position of a great power in the region and played an important role there in several different dimensions. The papers of this volume examine the political, diplomatic and military aspects of the Italian presence, as well as its economic, local and social dimension in post-Habsburg Central Europe. The intention of this thematic issue is not to cover the matter in its entirety, but rather to focus on lesser-known topics or those that have yet to be researched.
\end{abstract}

Keywords: international relations, social and economic history, Italy and Central Europe, immediate after-war, interwar period, Italy and Balkans

DOI: https://doi.org/10.31577/forhist.2021.15.1.1

$\mathrm{I}_{k}^{\mathrm{n}}$ n the autumn of 1918, after four years of the greatest conflict in the history of mankind up till that point, the armies of Entente and its allies fought to a definitive victory against the Central Powers. However, the ensuing period of stability did not come immediately to East-Central Europe, where the aftermath of the First World War lasted much longer than in the Western countries. The end of the war, the Paris Peace Conference (1919) and the reconstruction of the East-Central European region were some of the most important political, diplomatic and military milestones of the $20^{\text {th }}$ century. ${ }^{1}$ Creating successor states opened the question of drawing new borders, leading to new disputes among countries.

One of the consequences of the First World War was the dissolution, or notable internal weakening, of the four powers that traditionally maintained a strong influence on the Balkans and Central Europe. The disintegration of Austria-Hungary and the Ottoman Empire, the Russian Civil War and the weakening of Germany created a power vacuum, which Italy and France attempted to fill. This French-Italian rivalry had deeper roots and is one of the key components of this region in the interwar period. ${ }^{2}$ Some papers in this volume discuss the matter, others mention it more implicitly.

$1 \quad$ SHARP, Alan. Versailles 1919: A Centennial Perspective. London : Haus Publishing, 2018.

2 For more about the French-Italian rivalry in the Balkans and Central Europe, see LE MOAL, Frédéric. La France et l'Italie dans les Balkans, 1914-1919: le contentieux adriatique. Paris : Harmattan, 2006; NARDELLI-MALGRAND, Anne-Sophie. La rivalité franco-italienne en Europe balkanique et danubienne, de la conférence de la Paix de 1919 au pacte à Quatre de 1933. Intérêts nationaux et représentations du système européen. (manuscript of the $\mathrm{PhD}$. thesis) Paris : Université Paris 4, 2011. 
Italy had ambitions to become a great power mainly in the Balkan region, which Rome considered as a part of its sphere of influence, but also in Central Europe. Italy thus had an active policy towards the successor states which included its own military mission in Czechoslovakia, membership in the Allied Commission in Hungary and the annexation of several former Habsburg territories. Although these Italian territorial aspirations interfered directly with the Yugoslavia's desires, they also clashed with those of the USA and France.

Nevertheless, this new period of instability came to an end in the early 1920s. Italy had paid a high price for victory in the war-approximately 650,000 fallen-for which the public expected compensation in the form of new territories. A general belief prevailed that this was a "mutilated victory" - the name given by D'Annunzio—and the feeling that the Italians had been betrayed by the other Allies, who had not fulfilled the conditions of the Treaty of London of 1915 (the treaty that Italy signed with the Entente to enter the war). These factors made it easier for Mussolini to grab power at the beginning of the 1920s. ${ }^{3}$ Antonio Varsori admits that the Italian objectives were not completely satisfied but, according to him, Rome achieved most of the goals of the London Treaty of 1915, gaining a strong and strategic border with Yugoslavia and also with Austria by annexing South Tyrol (Alto Adige), which contained a mostly German speaking population. He writes that the "mutilated victory" was only a myth, but one effectively exploited by the fascists. ${ }^{4}$ Regardless, Mussolini's March on Rome had a significant influence on later Italian foreign policy.

The centenary of the First World War brought a new momentum into the research. "During the last decade, there has been a remarkable flow of new scholarly publications, especially in English, French and German, on both the First World War and the attempts by the victorious powers, starting with the Versailles Conference, to create a peaceful and stable international order." Recently, Italian political roles and diplomatic activities in the immediate after-war have also been analysed. ${ }^{5}$

However, relations between Italy and post-Habsburg Central Europe go far beyond political, diplomatic or military history. Diplomacy and political interests went hand in hand with economic concerns. Railway infrastructure played a key role in transportation during that period, making it crucial to establish a dominant position in train transport. As the First World War radically changed traditional social structures, this volume pays special attention to social history. At the time, a great number of former POWs returned home from Italy to new-born states and vice versa. The demilitarization of society was a primary task in the aftermath of the war and the situation at local levels could offer the new perspectives as well. As having had a part in the construction of New Europe became an important source of political capital, the question of historical memory is also brought up.

3 MACMILLAN, Margaret. Paris 1919: Six Months That Changed the World. New York : Random House, 2002.

4 VARSORI, Antonio. How to Become a Great Power: Italy in the New International Order, 1917-1922. In VARSORI, Antonio - ZACCARIA, Benedetto (eds). Italy in the New International Order, 1917-1922. Cham : Palgrave Macmillan, 2020, p. 12-13.

5 VARSORI 2020, p. 1. 
Naturally, the region of post-Habsburg Central Europe, or broadly, East-Central Europe, has been studied by Italian historians as a whole with the main aim of analysing Italian foreign policy towards the region. ${ }^{6}$ Looking at the Italian historiography country by country, due to the conflicting nature of Italian-Yugoslav relations in the first half of the $20^{\text {th }}$ century, Italian historiography dealt a lot with Yugoslav history. ${ }^{7}$ From post-Habsburg Central Europe, Italian historiography focused mainly on the history of Hungary thanks to the creation of the Inter-university Centre of Hungarian Studies in 1985, (Centro Interuniversitario di Studi Ungheresi in Italia). From 2000, it became the Inter-university Centre of Hungarian and Central-Eastern European, Studies (Centro Interuniversitario di Studi Ungheresi e sull'Europa Centro-Orientale), which shows a broadening of its specialisation. Though, the history of other countries is analysed as well ${ }^{8}$, priority is given to the intersection of Italian and East-Central European history, such as the Rome Congress of Oppressed Nationalities or Milan Rastislav Štefánik. ${ }^{9}$

Historians from the region are also interested in Italian history, or rather the Italian presence in post-Habsburg Central Europe. The intersection of Italy and post-Habsburg Central European history is the dominant concern $^{10}$, though, specifically "Italian" questions have also been explored. ${ }^{11}$

The ambition of this thematic issue is not to cover the matter in its entirety, but rather to bring attention to topics that are not as well known or have not been researched. We can divide the contributions into two parts: the first three papers cover specific questions of international relations, and the remaining four analyse rather topics related to local, social or economic history. From a chronological perspective, the period of immediate after-war is the most discussed, while the whole interwar time (in one case, even after the Second World War) is covered by three papers. As previously mentioned, these areas were researched mainly in Italian or in the respective languages of the nations in the region. By publishing this thematic issue in English, these matters become accessible to a wider international scientific public.

6 For example CACCAMO, Francesco. L'Italia e la «Nuova Europa». Il confronto sull'Europa orientale alla conferenza di pace di Parigi (1919-1920). Milano; Trento : Luni Editrice, 2000; SANTORO, Stefano. L'Italia e l'Europa orientale. Diplomazia culturale e propaganda 1918-1943. Milano : FrancoAngeli, 2005; CAPUZZO, Ester - CREVATO-SELVAGGI, Bruno - GUIDA, Francesco (eds). Per Rita Tolomeo, scritti di amici sulla Dalmazia e l'Europa centro-orientale I-II. Venezia : La Musa Talì, 2014; MOTTA, Guiseppe. Less Than Nations: Central-Eastern European Minorities After WWI, 2 Vol. Newcastle upon Tyne : Cambridge Scholars Publishing, 2013.

7 For more bibliographical data on this topic, see the references in the book RUDIĆ, Srđan - BIAGINI, Antonello VUČETIĆ, Biljana (eds). Serbian-Italian Relations: History and Modern Times. Belgrade : The Institute of History, Belgrade; Sapienza University of Rome, 2015.

8 GUIDA, Francesco. Romania. Milano : Unicopli, 2009. For more references, see GUIDA, Francesco. Historiographie italienne récente sur l'Europe centre-oriental d'une guerre mondiale à l'autre. In. SANDU, Traian (ed.) Illusion de puissance, puissance de l'illusion. Historiographies et histoire de l'Europe centrale dans les relations internationales de l'entre-deux-guerres. Paris : L'Harmattan, 2005, p. 57-67.

9 LEONCINI, Francesco (ed.) Il Patto di Roma e la Legione ceco-slovacca. Tra Grande Guerra e Nuova Europa. Vittorio Veneto : Kellermann Editore, 2014; MUSIL, Miroslav - BIAGINI, Antonello (eds.) Milan Rastislav Stefánik vo svetle talianskych archívov. Bratislava : Nadácia pre záchranu kultúrneho dedičstva, 2010.

10 PAVLOVIĆ, G. Vojislav (ed.) Italy's Balkan strategies $19^{\text {th }}$ \& $20^{\text {th }}$ century. Belgrade : Institute des études balkaniques, 2014; RAUCHOVÁ, Jitka - JIROUŠEK, Bohumil et al. Véda, kultura a politika $v$ československo-italských vztazích 1918-1951. České Budějovice: Jihočeské muzeum v Českých Budějovicích, 2012; BOKOR, Zsuzsa (ed.) În căutarea tărâmului promis: Italienii din România. Cluj-Napoca : Editura ISPMN, 2017.

11 HORVÁTH, Jenő. Olaszország Kelet-Közép-Európa politikája 1918-tól napjainkig. Grotius e-könyvtár, 2006 ; ORMOS, Mária. Mussolini I.-II. Budapest : PolgArt Könyvkiadó, 2000. 
Francesco Caccamo talks about the Italian position at the Paris Peace Conference on creating the borders of Czechoslovakia. Italy was interested in the possibility of economic and political influence in East-Central Europe. Because of that, Rome also had a special policy for the area, which was being shaped mainly by France. The first steps in this regard were made during the war by developing positive relations with the Czechoslovak National Council based in Paris. From a diplomatic point of view, Czechoslovak support of the Southern Slavs and their aspirations on the eastern Adriatic coast and planned Czechoslovak-Yugoslav corridor was not compatible with the Italian interests. The author comprehensively reconstructs the Italian position towards the Czechoslovak demands, mainly the negotiations within the Commission for Czechoslovak Affairs and Supreme Council and concludes that Italy was the one member among the great powers that exhibited the most reservations towards these territorial ambitions of the young state.

As Petra Hamerli outlines in detail, Italy and Hungary shared a similar position towards Yugoslavia. This state was the main obstacle for Italian foreign policy in Europe, which sought to gain influence in the Balkans, Central-Europe and the Mediterranean - especially after Mussolini came to power. Due to its revisionist foreign policy, Hungary had also interest in weakening the South-Slavic state. Hamerli, in her case study of the support of the Internal Macedonian Revolutionary Organization (IMRO) by Italy and Hungary, shows the close cooperation of the two states in backing the separatist movements organized within Yugoslavia. If the IMRO had the support of these two countries, it was not considerable as both were afraid of being compromised by its violent actions.

Stefano Santoro studies a different dimension of Italian penetration in East-Central Europe mainly during the interwar period, paying special attention to the case of Czechoslovakia. Santoro understands that culture and propaganda were instruments that allowed Italy to compete, mainly with France, for hegemony in East-Central Europe. In January 1921, the Institute for Eastern Europe (Istituto per l'Europa Orientale), was established in Rome. This initiative was personally supported by the foreign minister of Italy and its main goal was to strengthen Italian cultural policies in East-Central Europe. Soon after, cultural institutes, ("Institutes of Italian Culture", later renamed "Italian Institutes of Culture") followed. As Santoro states, France did basically the same and established a network of Instituts français. The main task of Italian cultural diplomacy in the late 1930s was to spread a revisionist policy of fascists against Yugoslavia. However, Italy lost its position in this sphere definitively after the Second World War.

Biljana Stojić analyses the Yugoslav ruling over Rijeka, (Fiume), in 1918, describing it through the war experience and writings of Stanislaw Krakow. He was only 22 in 1918, but had already survived seven years of warfare that had begun in 1912 for him. His story is almost unbelievable. By the end of the war, he was wounded 14 times in total, suffered from mumps, cholera, malaria, Spanish flu and was awarded 18 medals. In the interwar period, he was a man of many professions. The author chose Krakow as he had rich personal experience and was witness to conflicts between pro-Yugoslavs and pro-Italians. Of course, he was not neutral minded. It is important to mention that Krakow was mostly pro-Yugoslav. 
Juhász Balázs' research draws attention to Hungarian POWs and their journey home, which was not easy or fast. Ethnicity together with political and ideological concerns were crucial determiners of who returned home first. POWs had access to assorted press reports and were able to follow events in their home countries. A contributing factor was that POWs were used as a cheap labour force, responsible for filling war trenches, collecting scrap metal and explosives, and preparing the land for agricultural production. The possibility to enlist Hungarian POWs to fight Hungarian Bolsheviks also emerged but was not realised. Except for a few cases, the mass repatriation of Hungarian POWs was not possible until August 1919. Juhász presents this issue from both the Hungarian and Italian points of view. Anne-Sophie Nardelli-Malgrand addresses the issue of transport infrastructure, and especially the railways. Railways are always described as a tool of political and economic penetration. The extensive European railway networks were finished mostly during the second half of the $19^{\text {th }}$ century. This network served each state who had a planned transport policy and financed its construction. However, a problem appeared immediately after the First World War and after the establishment of the successor states and their borders. It happened sometimes, for instance, that an important railway station was left behind a border and without a special agreement between the states, the whole area was without transport. The importance of these transport issues was also highlighted by the fact that the Railway Committee worked as an integral part of the Paris Peace Conference. The abovementioned Commission was later replaced by an International Wagon Exchange Committee led by a French civil servant instead of army officers. This was not in accordance with the Italian railway policy in Central Europe and post-Habsburg territories. Italy wanted to use its political and financial influence to have control over some of the great railway companies. Nardelli-Malgrand analysed the details of this ambitious strategy.

Michal Kšiňan and Juraj Babják focus their paper on Italian-Czechoslovak military cooperation (1918-1919) in the official historical memory of the interwar period. The authors detail two dimensions of the memorialisation of Italian-Czechoslovak military cooperation in 1918-1919, one pertaining to ceremonies and the formal aspects of remembrance, and the other to the effects of international politics-specifically, the often-turbulent Italian-Czechoslovak relations-on commemorative practices. First, they present some context; the emergence and early days of Italian-Czechoslovak military cooperation between 1918-1919 and Italian-Czechoslovak relations in the interwar period. Next, three important events are the focus: the $10^{\text {th }}$ anniversary of Czechoslovakia in 1928, the tragic death of General Graziani in February 1931, and the celebrations of 1938. Aside from ceremonies, the authors also examine Czechoslovak legionnaire monuments and cemeteries in both Italy and Czechoslovakia as places of historical memory. The political situation of the time shaped the commemorations greatly as the heroic side of military cooperation was put forward and its "less heroic" aspects forgotten. The construction of monuments and maintenance of the cemeteries also played an important role in this context. The historical legacy of the Czechoslovak Legion and its subsequent military cooperation mainly with France and to a lesser extent, with Italy, formed the basis of the Czechoslovak military tradition. 
This thematical issue shows an expansion towards topics no longer exclusively devoted to political, military and diplomatic history. In total, eight authors present their research in seven papers, proving that there remains a knowledge gap in some areas. Their contributions are significant in gaining a better understanding of the post-war and inter-war era, and also the Italian presence in post-Habsburg Central Europe, and more broadly, in the European historical context.

\section{Cite:}

KŠIŇAN, Michal - ĎURČO, Michal. Italy and Post-Habsburg Central Europe (An Introduction). In Forum Historiae, 2021, Vol. 15, No. 1, pp. 1-6. ISSN 1337-6861. DOI: https://doi.org/10.31577/forhist.2021.15.1.1

Michal Kšiňan

Historický ústav SAV

P. O. Box 198, Klemensova 19

81499 Bratislava

email: michal.ksinan@savba.sk
Michal Ďurčo

Historický ústav SAV

P. O. Box 198, Klemensova 19

81499 Bratislava

email: michal.durco@savba.sk 